\title{
Landslide Hazard Zonation of Sunkoshi -2 High Dam Project area using Quantitative Methods in Geographical Information Science
}

\author{
Sakunda Ojha, Sobit Thapaliya \\ Sanima Hydro and Engineering Pvt. Ltd., Nepal
}

\begin{abstract}
Landslides are one of the critical geological processes, which causes not only enormous damage to civil engineering structures such as hydropower plant, road, bridges, dams and houses but also lead to loss of life. The construction of hydropower projects involve disturbance to the natural slop making them vulnerable to landslides. Therefore, there is a need for landslide hazard zonation so that hazardous area could be stabilized before it escalates major disaster. The present study attempts to develop a landslide model by using multi-criteria decision analysis using Geographical Information Science (GIS) and remote sensing techniques.
\end{abstract}

The proposed Sunkoshi -2 High Dam Project area was selected for the model implementation. Digital topographical data, regional geological maps, remote sensing image and field data were used as inputs to the study. The data layers represent the elevation, drainage, soil type, geology (geological faults and existing landslide), slope, aspects and land use. A numerical rating scheme for the factors was developed for spatial data analysis in GIS. The resulting landslide hazard zonation map delineates the area into different zones of three relative classes: High, Medium and Low. The present study shows that the implementation of Sunkoshi - 2 High Dam Project would make the areas at the reservoir water level more vulnerable towards landside.

Keywords—Landslide hazard zonation, multi-criteria decision analysis, quantitative methods in GIS

\section{Introduction}

Landslides in mountainous terrain often occur during or after heavy rainfall, resulting in the loss of life and damage to the natural and /or built environment (Fuchu et al., 2002). Earthquakes, heavy rainfall and volcanic eruptions act as natural triggering mechanisms to initiate a landslide (Kessarkar et al. 2011). On the other hand, human activities such as disturbance to the natural slopes (slope cutting) and deforestation are the anthropogenic triggering mechanism. In a high dam reservoir type projects, the frequent fluctuation in the reservoir water level will make the adjoining slope vulnerable to landslide due to variation in pore water pressure.
Though landslides and related disasters occur frequently in the fragile and young Himalayan region of Nepal, there are only few studies carried out focusing on the extend, type and cause of such disasters. Very few attempts have been made on hazard mitigation and to prepare maps depicting the hazard and/or risk associated with these events. So far, the work on landslide studies in Nepal is widely scattered.

\section{Description of the study area}

The proposed Sunkoshi - 2 High Dam Project (1,110 MW) was first identified in the Koshi Basin Master Plan Study (JICA 1985). The project plans to construct a $166 \mathrm{~m}$ high dam across the Sunkoshi River along with a dam-toe power station at the left bank of the river.

Geographically, the project area is located between longitudes $86^{\circ} 10^{\prime} 20^{\prime \prime} \mathrm{E}$ to $85^{\circ} 47^{\prime} 30^{\prime \prime} \mathrm{E}$ and latitude $27^{\circ} 14^{\prime} 00^{\prime \prime} \mathrm{N}$ to $27^{\circ} 29^{\prime} 30^{\prime \prime} \mathrm{N}$ between $400 \mathrm{~m}$ asl to $600 \mathrm{~m}$ asl. The entire project components and the inundation area will be located within Sindhuli (10 VDCs), Ramechhap (23 VDCs), Kavrepalanchowk (5 VDCs) and Dolakha (1 VDC) districts of Central Development Region of Nepal.

The scheme will impound about $80 \mathrm{~km}$ of the river stretch and its tributaries, creating a reservoir. The reservoir will have a surface area of approximately $70 \mathrm{~km}^{2}$ at full supply level, a gross storage capacity of 4.37 billion $\mathrm{m}^{3}$ and an effective storage of 3.04 billion $\mathrm{m}^{3}$. The installed capacity of the scheme has been estimated to be $1,110 \mathrm{MW}$, with an annual energy generation capacity of 4,760 GWh (JICA 1985). The project area location map is shown in Figure 1. 


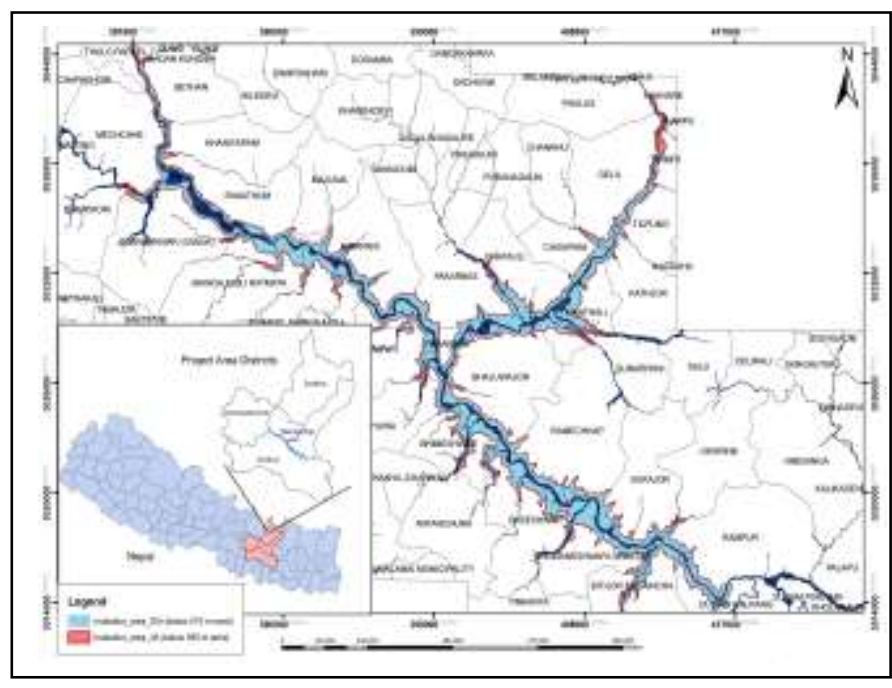

Figure 1: Project Area Location Map

\section{Data Used and Methodology}

Table 1: Different data layers / maps and sources

\begin{tabular}{|c|c|}
\hline Data Layer & Sources \\
\hline $\begin{array}{l}\text { Remote Sensing } \\
\text { Data }\end{array}$ & ASTER (DEM) (30 m) \\
\hline Topographical map & $\begin{array}{l}\begin{array}{l}\text { Department of Survey } \\
\text { Government of }\end{array} \text { Nepal } \\
\text { (GoN) } \\
\text { Topographical Map at } 1: 25,000 \text { scale }\end{array}$ \\
\hline $\begin{array}{lr}\text { Land use } & \text { / Land } \\
\text { Cover } & \text { Mapping } \\
\text { (LULC) } & \end{array}$ & $\begin{array}{l}\text { Digital LULC map have been } \\
\text { prepared by using } \\
\text { Classification Tool in ArcGIS } \\
-9.3\end{array}$ \\
\hline Soil Map & $\begin{array}{l}\text { Soil map of the area has been prepared } \\
\text { as per the information from field } \\
\text { investigation. }\end{array}$ \\
\hline Geological map & $\begin{array}{l}\text { Regional Geological Map of project } \\
\text { area (Source: Modified after DMG, } \\
\text { 1984) }\end{array}$ \\
\hline $\begin{array}{l}\text { Drainage density, } \\
\text { Slope and aspect } \\
\text { Map }\end{array}$ & $\begin{array}{l}\text { Drainage network and drainage } \\
\text { density have been created in GIS } \\
\text { environment using DoS Map at } \\
1: 25,000 \text { scales. Slope and aspect } \\
\text { maps have been created using Spatial } \\
\text {-Analyst Extension in ArcGIS-9.3 and } \\
\text { Aster (DEM) data. }\end{array}$ \\
\hline $\begin{array}{l}\text { Existing Landslide } \\
\text { and Location of } \\
\text { Main Central Thrust } \\
\text { Map }\end{array}$ & $\begin{array}{l}\text { Existing landslides and location of } \\
\text { MCT have been mapped through field } \\
\text { investigation and referenced from } \\
\text { regional geological map. }\end{array}$ \\
\hline
\end{tabular}

Figure 2: Drainage density map of the project area

Geological Structures: The major rock type of the project area are south dipping biotite schist, psammatic schist, quartzite and few carbonate bands which are intruded by injection gneisses. The Main Central Thrust (MCT) zone runs along the right bank of Sunkoshi River at the region upstream from the confluence of Sunkoshi River and Tamakoshi River. 
Proc. of the Intl. Conf. on Advances in Applied science and Environmental Technology - ASET 2015.

Copyright (C) Institute of Research Engineers and Doctors, USA .All rights reserved.

ISBN: 978-1-63248-040-8 doi: 10.15224/ 978-1-63248-040-8-31

The thrust crosses the river at the confluence and runs along the left bank passing the proposed dam and powerhouse area.

Some active landslides were observed in the project area along some stretch of MCT. Since, the MCT is sheared zone; the seismic waves generated due to tectonic activity triggers the landslide around this zone. Figure 3 shows the regional geology map of the project area.

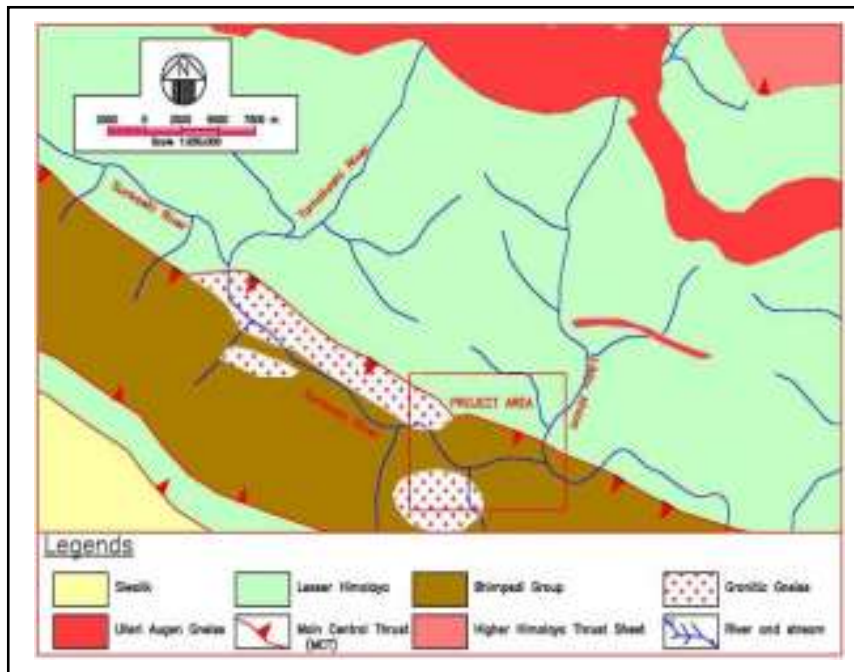

Figure 3: Regional Geological Map of project area (Source: Modified after DMG, 1984)

Slope gradient: Slope plays an important role in governing the stability of a terrain. As the slope increases, chances of slope failure also increase. However, variations in soil thickness and strength are two factors which vary over a wide range for both failure and non-failure sites (Borga, et al. 2002).

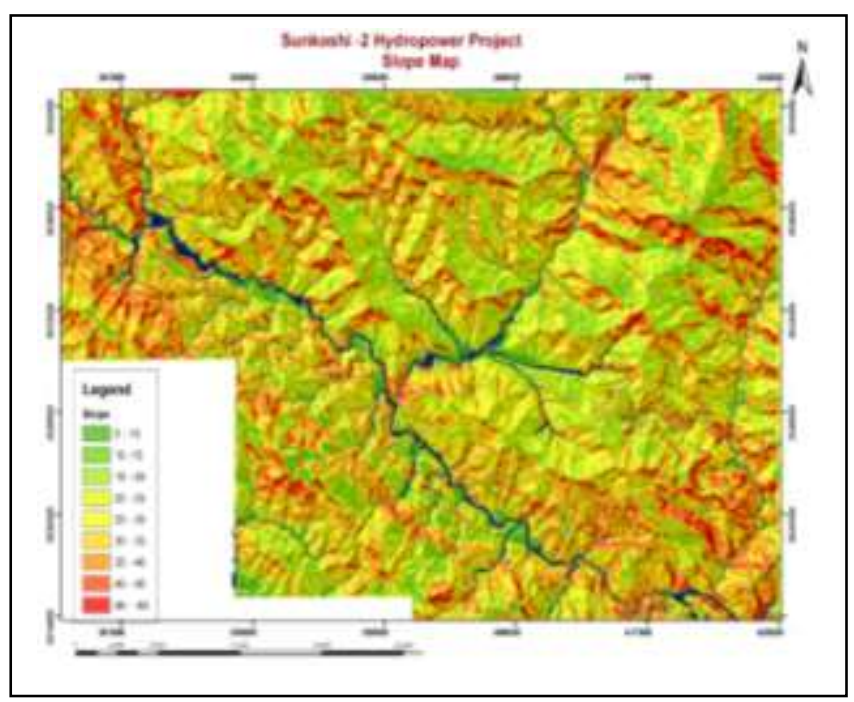

Figure 4: Slope Map of the project area

Aspect: The related parameters of aspect such as exposure to sunlight, drying winds, rainfall and discontinuities control the occurrence of landslides. Aspect degree are classified according to the aspect class as flat, north, east, south and west. The slope aspect map of the project area is shown in Figure 5.

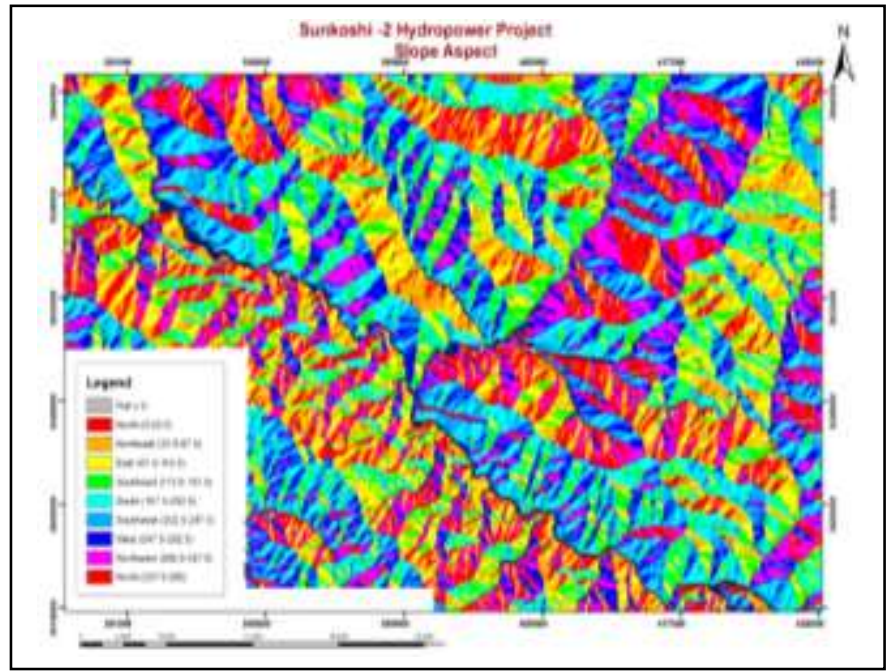

Figure 5: Slope Aspect Map of the project area

Land Use and Land Cover: Land use and land cover play an important role in instability of slope. Studies have shown that land-use or vegetation cover, especially of a woody type with strong and large root systems, help to improve stability of slopes (Dai et al. 2002).

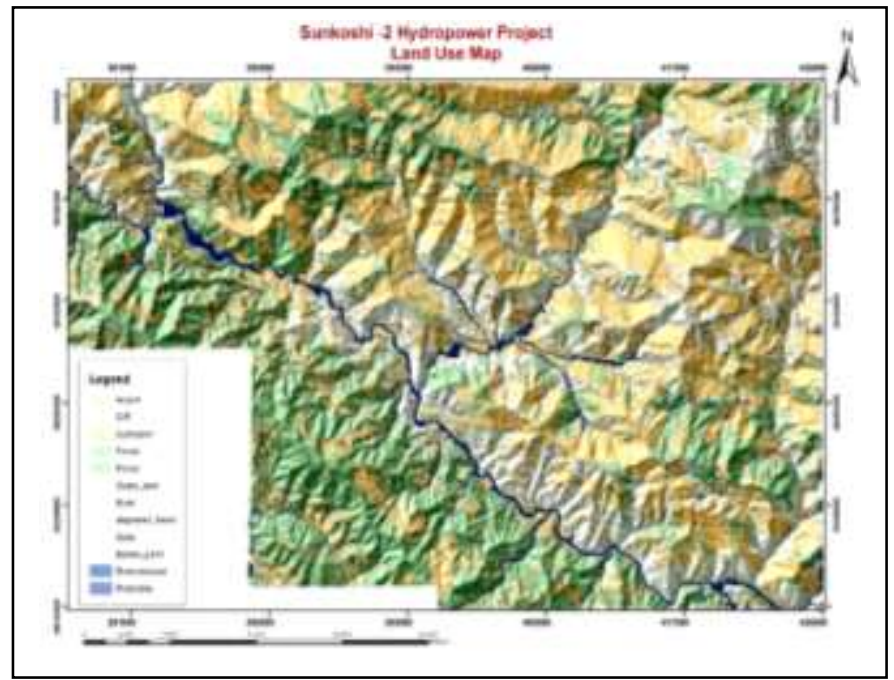

Figure 6: Land use Map of the project area

Soil Type: The major soil types found in the project area are alluvial soil, residual soil and colluvial soil. Alluvial soil is present on either side of river terraces and consists of sand, gravel and boulder. Residual soil is present on the old terrace that consists of settlement and cropland. Colluvial soil is present along the gentle slope of the mountain and old landslide area. The soil cover of the project area is closely related with the land use pattern. 
Proc. of the Intl. Conf. on Advances in Applied science and Environmental Technology - ASET 2015.

Copyright (C) Institute of Research Engineers and Doctors, USA .All rights reserved.

ISBN: 978-1-63248-040-8 doi: 10.15224/ 978-1-63248-040-8-31

\section{Landslide Hazard Zonation}

The landslide hazard zonation map has been prepared by computing landslide potential index and classifying landslide potential index into several landslide susceptible zones such as low, medium and high. The landslide potential index is defined as:

Landslide Potential Index $(\mathrm{LPI})=\sum \mathrm{n} \mathrm{i}=1(\mathrm{Ri} * \mathrm{Wi})$

Where $\mathrm{Ri}$ denotes the rank for factor $\mathrm{i}$ and $\mathrm{Wi}$ denotes the weight of class of factor $i$. In this study, the total number of factors $(n)$ is eight.

Rank and weights of factors for landslide: The landslide hazard evaluation factor weights scheme is a numerical system that depends on the relevant factor. Ranks and weights of causative factors (parameters) need to be assigned in order to generate a landslide hazard zonation map. The relevant factor for landslide hazards zonation mapping shall include the major factors such as terrain slope, terrain height, drainage density, soil type, land use, aspect, presence of major geological faults and existing landslides. The stability of an area depends on the combined effects of the factors indicated above. The maximum landslide hazards evolution factor weights for different categories are determined based on their estimated significance in causing instability.

Table 2: Rank and weights of factors for landslide

\begin{tabular}{|c|c|c|c|c|}
\hline Factor & Classes & $\begin{array}{l}\text { Ranks } \\
(\mathrm{Ri}), \\
\text { in \% }\end{array}$ & $\begin{array}{l}\text { Weights } \\
\text { (Wi) }\end{array}$ & Remarks \\
\hline $\begin{array}{l}\text { Terrain } \\
\text { Height (m } \\
\text { asl) }\end{array}$ & $\begin{array}{l}370-400 \\
400-500 \\
500-600 \\
600-700 \\
700-800 \\
>2000\end{array}$ & 13 & $\begin{array}{l}8 \\
9 \\
10 \\
8 \\
6 \\
1\end{array}$ & $\begin{array}{l}\text { The } \\
\text { elevation } \\
\text { range } \\
\text { between } \\
500 \text { - } 600 \text { is } \\
\text { vulnerable } \\
\text { as it is the } \\
\text { reservoir } \\
\text { water } \\
\text { fluctuation } \\
\text { level. }\end{array}$ \\
\hline Land use & $\begin{array}{l}\text { Airport } \\
\text { Rock } \\
\text { exposure } \\
\text { Cultivation } \\
\text { Forest } \\
\text { Grass land } \\
\text { Bush land } \\
\text { Degraded } \\
\text { Forest } \\
\text { River bank } \\
\text { Barren land }\end{array}$ & 12 & $\begin{array}{l}1 \\
1 \\
5 \\
2 \\
7 \\
7 \\
\\
8 \\
8 \\
9\end{array}$ & $\begin{array}{l}\text { Land use } \\
\text { type such as } \\
\text { barren land, } \\
\text { degraded } \\
\text { forest, bush } \\
\text { land, } \\
\text { grassland } \\
\text { and } \\
\text { agricultural } \\
\text { land are } \\
\text { highly susceptible } \\
\text { to landslide. }\end{array}$ \\
\hline Soil Type & Alluvial & 11 & 5 & Colluvial \\
\hline
\end{tabular}

\begin{tabular}{|c|c|c|c|c|}
\hline Factor & Classes & $\begin{array}{l}\text { Ranks } \\
\text { (Ri), } \\
\text { in \% }\end{array}$ & $\begin{array}{l}\text { Weights } \\
\text { (Wi) }\end{array}$ & Remarks \\
\hline & $\begin{array}{l}\text { Colluvial } \\
\text { Residual }\end{array}$ & & $\begin{array}{l}9 \\
7\end{array}$ & $\begin{array}{l}\text { soil is the } \\
\text { product of } \\
\text { landslide, } \\
\text { present on } \\
\text { older } \\
\text { landslide } \\
\text { and sloppy } \\
\text { area. }\end{array}$ \\
\hline Aspect & $\begin{array}{l}\text { Flat } \\
\text { North } \\
\text { Northeast } \\
\text { East } \\
\text { Southeast } \\
\text { South } \\
\text { Southwest } \\
\text { West } \\
\text { Northwest }\end{array}$ & 10 & $\begin{array}{l}\text { Null } \\
8 \\
7 \\
4 \\
2 \\
1 \\
3 \\
4 \\
5\end{array}$ & $\begin{array}{l}\text { North } \\
\text { facing } \\
\text { slopes are } \\
\text { susceptible } \\
\text { to landslide } \\
\text { due to } \\
\text { lower vegetation } \\
\text { and moist } \\
\text { soil (low } \\
\text { sunlight) }\end{array}$ \\
\hline $\begin{array}{l}\text { Terrain } \\
\text { Slope } \\
\text { (degree) }\end{array}$ & $\begin{array}{l}25-30 \\
30-35 \\
35-40 \\
40-45 \\
45-60\end{array}$ & 16 & $\begin{array}{l}5 \\
6 \\
7 \\
8 \\
9\end{array}$ & $\begin{array}{l}\text { Steeper } \\
\text { slopes } \\
\left(>40^{\circ}\right) \text { are } \\
\text { prone to } \\
\text { landslide. }\end{array}$ \\
\hline $\begin{array}{l}\text { Drainage } \\
\text { Density }\end{array}$ & $\begin{array}{l}\text { High } \\
\text { Medium } \\
\text { Low }\end{array}$ & 14 & $\begin{array}{l}9 \\
4 \\
1\end{array}$ & $\begin{array}{l}\text { The area } \\
\text { with higher } \\
\text { drainage } \\
\text { density has } \\
\text { greater } \\
\text { possibilities } \\
\text { for } \\
\text { landslide. }\end{array}$ \\
\hline $\begin{array}{l}\text { Existing } \\
\text { Landslide } \\
\text { (distance in } \\
\text { meters } \\
\text { from } \\
\text { centre) }\end{array}$ & $\begin{array}{l}0-5 \\
5-10 \\
10-15 \\
15-20 \\
>40\end{array}$ & 15 & $\begin{array}{l}9 \\
8 \\
7 \\
6 \\
1\end{array}$ & $\begin{array}{l}\text { The area of } \\
\text { and } \\
\text { adjoining to } \\
\text { the existing } \\
\text { landslides } \\
\text { are } \\
\text { susceptible } \\
\text { to landslide }\end{array}$ \\
\hline $\begin{array}{l}\text { Presence of } \\
\text { geological } \\
\text { thrust, } \\
\text { MCT } \\
\text { (distance in } \\
\mathrm{km} \text { ) }\end{array}$ & $\begin{array}{l}0-5 \\
5-10 \\
>40\end{array}$ & 9 & $\begin{array}{l}9 \\
6 \\
1\end{array}$ & $\begin{array}{l}\text { Greater } \\
\text { tectonic } \\
\text { activities at } \\
\text { MCT zone. } \\
\text { However, } \\
\text { the project } \\
\text { itself will } \\
\text { not cause to } \\
\text { accelerate } \\
\text { such } \\
\text { activities. }\end{array}$ \\
\hline
\end{tabular}

The important factors responsible for the landslides were rated as percentage. Weights were assigned to the factors on 0 to 9 scales, where higher weight indicates a greater susceptibility 
Proc. of the Intl. Conf. on Advances in Applied science and Environmental Technology - ASET 2015.

Copyright (C) Institute of Research Engineers and Doctors, USA .All rights reserved.

ISBN: 978-1-63248-040-8 doi: 10.15224/ 978-1-63248-040-8-31

to landslide occurrence. The details of ranks and weights for factors and their classes are presented in Table 2. After collecting pertinent data from the available sources described earlier, initial data maps were re-classified according to the weights given in Table 2 .

Total Estimated Landslide Hazard Zonation (TELHZ) values: The landslide model is created and the ranks and weights are assigned to each category.

TELHZ Value $=T_{H}+L_{U}+S_{T}+S_{A}+T_{S}+D_{D}+E_{L}+G_{T}$

Where, TELHZ Value $=$ Sum of Ratings of all causative Factors, $\mathrm{T}_{\mathrm{H}}=$ Terrain Height, $\mathrm{L}_{\mathrm{U}}=$ Land use, $\mathrm{S}_{\mathrm{T}}=$ Soil Type, $\mathrm{S}_{\mathrm{A}}=$ Slope Aspect, $\mathrm{T}_{\mathrm{S}}=$ Terrain Slope, $\mathrm{D}_{\mathrm{D}}=$ Drainage Density, $\mathrm{E}_{\mathrm{L}}=$ Existing landslides and $\mathrm{G}_{\mathrm{T}}=$ Major Geological Thrust

Based on TELHZ values three landslide hazard zones were categorized as shown in Figure 7.

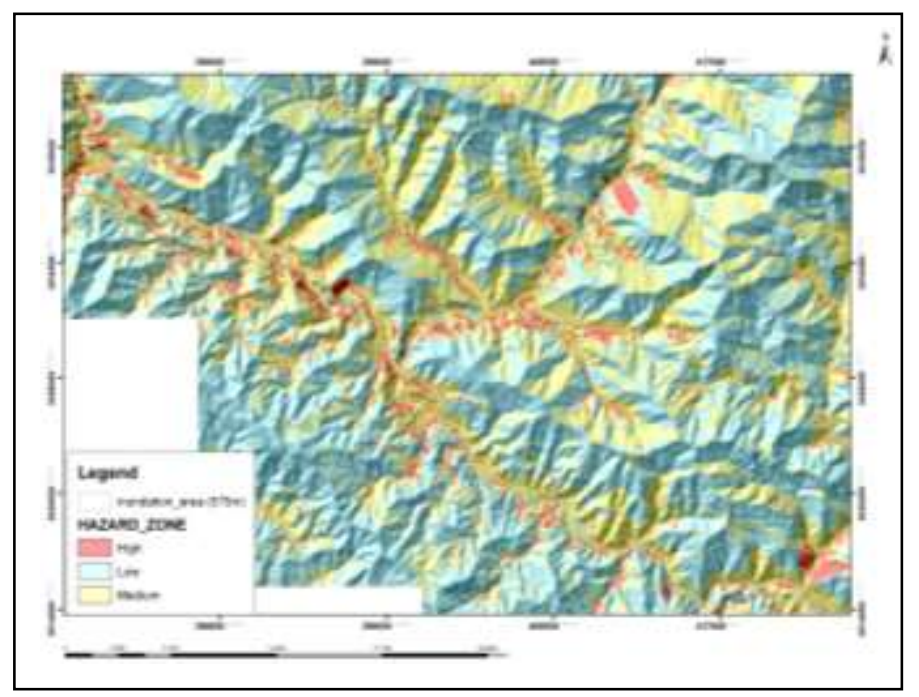

Figure 7: Landslide Hazard Map of the project area

\section{v. Conclusion}

The present study shows the application of GIS and remote sensing technique in landslide hazard mapping. The study identified the areas that will be prone to landslide during the project implementation. The area particularly the reservoir water level should be treated with greater care to minimize the landslide hazard during the reservoir operation. Further risk analysis (depending upon the households located on the high hazard zone) is recommended for planning the evacuation, resettlement and landslide protection measures.

\section{Acknowledgment}

The author is grateful to Mr. Ajoy Karki, Director of Sanima Hydro and Engineering Pvt. Ltd, for providing necessary facilities and my supervisor Dr. Subarna Das Shrestha for motivation to conduct this work.

\section{References}

1) Borga, M., Fontana, G.D., Gregoretti, C., and Marchi, L., 2002. Assessment of shallow landsliding by using a physically based model of Hillslope stability. Hydrological Processes, Vol. 16, pp. 2833 - 2851.

2) Dai, F.C., and Lee, C.F., 2002. Landslide Characteristics and slope instability modeling using GIS, Lantau Island, Hong Kong. Geomorphology (Elsevier), Vol. 42, pp. 213 - 228.

3) Fuchu, D., and Chack F.L., 2002. Landslides on natural terrain physical characteristics and susceptibility mapping in Hong Kong. Mountain Research and Development, Vol. 22(1), pp. 40-47

4) JICA., 1985. Koshi Basin Master Plan Study

5) Kessarkar, P.M., Srinivas, K. Suprit, K., and Chaubey, A.K., 2011. Proposed landslide mapping method for Canacona region. National institute of Oceanography, (Council of Scientific and Industrial Research, Dona Paula, Goa,) pp. 5.

About Author:

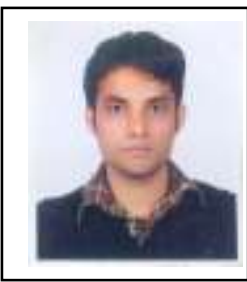

Mr. Sakunda Ojha is an environmentalist with six years of experience in hydropower sector. He has worked in number of hydropower projects ranging from $990 \mathrm{~kW}$ to $1110 \mathrm{MW}$ in Nepal. He

has authored various publications in energy and ecological sector. Mr. Ojha

holds M.Sc. degree from Tribhuvan University, Nepal. He currently works as a senior environmentalist to Sanima Hydro and Engineering Pvt. Ltd. 